\title{
Major Challenges and Remedies in Building the Bangladesh-China- India-Myanmar Economic Corridor
}

Md. Safiqul Islam, Huang Ailian and Zhang Jie

\begin{abstract}
Although the Bangladesh-China-India-Myanmar Economic Corridor (BCIM-EC) has the potential to enhance economic and geo-strategic benefits of the four participating countries in the long run, its building process has often been stagnated due to India's lingering concern about the implications of the Corridor for its national security and, more importantly, to the growing competition among major countries including China, the United States and India. Moreover, there remains ethnic
\end{abstract}

Md. Safiqul Islam is a PhD Candidate in Global Studies, School of Liberal Arts, Shanghai University, and Associate Professor at the Department of Political Science, University of Chittagong, Chittagong 4331, Bangladesh. He can also be reached at safiqcu@shu.edu.cn. Professor Huang Ailian and Associate Professor Zhang Jie work at the China-ASEAN Research Institute, Guangxi University. They can be reached at gxhuangailian@163.com and jiezhang@gxu.edu.cn, respectively.

(c) 2018 World Century Publishing Corporation and Shanghai Institutes for International Studies China Quarterly of International Strategic Studies, Vol. 4, No. 4, 613-629

DOI: $10.1142 / S 2377740018500306$

This is an Open Access article, copyright owned by the SIIS and WCPC. The article is distributed under the Creative Commons Attribution 4.0 (CC BY-NC) Licence. Further distribution of this work is permitted, provided the original work is properly cited and for non-commercial purposes. 
insurgency in Northeast India and Myanmar as well as the Rohingya issue between Bangladesh and Myanmar, which poses lasting security threats to the building of the Corridor. By analyzing the nature of those challenges, this article shows that the emerging Indo-U.S. strategic coalition for checking China's influence and India's reluctant stance in building the BCIM-EC are the biggest challenges, whereas neither the ethnic insurgency nor the Rohingya issue can affect BCIM-EC building substantially. Therefore, it is concluded that the BCIM-EC cannot succeed unless China and India can both fully commit to the building process while enhancing all-round cooperation based on their mutual strategic trust.

Keywords: Bangladesh-China-India-Myanmar Economic Corridor (BCIMEC); core capitalist country; strategic distrust; security risk.

\section{The BCIM-EC: An Integral Part of China's BRI}

The Bangladesh-China-India-Myanmar (BCIM) Forum for Regional Cooperation, earlier known as the "Kunming Initiative" at its inception in 1999, aims at creating a sub-regional cooperation zone linking the relatively backward regions of southwest China and northeast India through Bangladesh and Myanmar. In particular, invoking rhetoric of the ancient southern Silk Road, the BCIM Forum seeks to restore the historical arteries of overland connectivity that once linked India's northeastern states with China's southwestern province of Yunnan through present-day Bangladesh and northern Myanmar. ${ }^{1}$ In February 2012, officials from the four countries approved the road map of developing the 2,800-km highway from Kolkata (capital city of West Bengal of India) to Kunming (capital city of Yunnan Province of China) through Bangladesh, Northeast India and Myanmar, which would be the first expressway connecting China and Southeast Asia to South Asia; ${ }^{2}$

${ }^{1}$ Patricia Oberoi, The BCIM Forum: Retrospect and Prospect (Delhi: Institute of Chinese Studies, 2013), p. 2, http://www.icsin.org/uploads/2015/04/12/df72872d10c0497 dadfb52322bafd900.pdf.

${ }^{2}$ Mohammed Rahmatullah, "Strengthening Connectivity among BCIM Countries," Presentation at the Eleventh BCIM Forum, Centre for Policy Dialogue, Dhaka, February 23-24, 2013, http://www.cpd.org.bd/11BCIM/PapersSession\%20IIStrengthening\%Multimodal \%20Connectivity/M\%20Rahmatullah.pdf. 
the historical "BCIM Car Rally" was held in February 2013 to strengthen the notion. ${ }^{3}$

In September 2013, Chinese President Xi Jinping proposed the grand new vision of the Belt and Road Initiative (BRI), which promotes Eurasian connectivity and includes the road map for the BCIM Economic Corridor (BCIM-EC). The BCIM-EC is planned to extend on three routes: one, known as $\mathrm{K} 2 \mathrm{~K}$, will run from Kunming to Kolkata via Myanmar, Northeast India and Bangladesh; the other two will go from Mandalay of Myanmar to Chittagong of Bangladesh in one direction, and to Sittwe seaport at Rakhine state of Myanmar in another direction. With the linkages of transport, energy and telecommunications networks, it is expected to promote common development for areas along the Corridor. ${ }^{4}$

Nevertheless, China and India, as major emerging countries, are vying with each other to secure their respective strategic and economic interests in the Pacific and the Indian Ocean regions. India, under the Modi government in particular, worries about losing its dominant position in the Bay of Bengal region to China with the BCIM-EC (although it was an active participant in the BCIM Forum under former Indian Prime Minister Manmohan Singh). Thus, despite pronounced support for the plan, the Indian government has appeared to be ambivalent, if not wavering, in its commitment to jointly build the BCIM-EC. In addition, ethnic conflicts in northeast India and Myanmar, as well as the Rohingya crisis between Bangladesh and Myanmar, all pose security challenges to the Corridor.

Over the past few years, the BCIM-EC has attracted growing academic attention. For example, Patricia Uberoi has critically reviewed the Indian perspective of the Corridor. ${ }^{5}$ Gurudas Das and some other scholars emphasize the geo-economic significance of sub-regional cooperation and

${ }^{3}$ Aparna Sharma and Chetna K. Rathore, “BIMSTEC and BCIM Initiatives and their Importance for India," Discussion Paper for CUTS Centre for International Trade, Economics \& Environment, 2015, p. 12, http://www.cuts-citee.org/pdf/BIMSTEC_and_BCIM_Initiatives_ and_their_Importance_for_India.pdf.

${ }^{4}$ Patricia Uberoi, The BCIM Economic Corridor: A Leap into the Unknown? (Delhi: Institute of Chinese Studies, November 2014), p. 3, http://www.icsin.org/uploads/2015/05/15/ 89cb0691df2f a541b6972080968fd6ce.pdf.

${ }^{5}$ Patricia Uberoi, "Problems and Prospects of BCIM Economic Corridor," China Report, Vol. 52, No. 1 (2016), pp. 19-44. 
connectivity for land-locked areas in the context of the BCIM. ${ }^{6}$ Professor Wang Yong has also carefully examined the strategic aspect and geopolitical challenges of the BRI and misperception about China's presence in South Asia. ${ }^{7}$ In all, the existing literature mainly focuses on the economic aspect from the Indian perspective, or the strategic and geopolitical aspects of the BRI as a whole, but has hardly addressed the challenges of building the BCIM-EC as an integral part of the BRI. Therefore, this paper explores the causes of the major challenges to the building process of the BCIM-EC and gives suggestions on how they should be tackled.

\section{Competition Among Core Capitalist Countries}

The primary challenge of building the BCIM-EC can be analyzed through the lens of Kautsky's theory on ultra-capitalism and Lenin's theory on imperialism. Kautsky argues that the catastrophe of WWI will bring about a competitive capitalist alliance or cartel which compels national finance capitals to cooperate internationally; ${ }^{8}$ Lenin's theory views that imperialism has become identified with the expansionist drive that inevitably generates imperialist wars of division and redivision among the world's core capitalist powers. 9

Although China remains a socialist country "with Chinese characteristics" in its official discourse, it has adopted many capitalist traits as its economy integrates ever more deeply into the world market - not only because it is

China has become a major player in global capitalist competition.

${ }^{6}$ Gurudas Das, Ujjwal K. Paul and Tanuj Mathur, "Sub-regional Cooperation for the Development of Landlocked Peripheral Areas: The Case of BCIM," South Asian Survey, Vol. 20, No. 1 (2013), pp. 74-93; see also Zaara Zain Hussain, "The BCIM Regional Cooperation: An Emerging Multilateral Framework in Asia," Geopolitics, History, and International Relations, Vol. 7, No. 2 (2015), pp. 173-189.

${ }^{7}$ Yong Wang, “Offensive for Defensive: The Belt and Road Initiative and China's New Grand Strategy," Pacific Review, Vol. 29, No. 3 (2016), pp. 455-463.

${ }^{8}$ Ibid, p. 94.

${ }^{9}$ John A. Willoughby, “The Lenin-Kautsky Unity-Rivalry Debate," Review of Radical Political Economics, Vol. 11, No. 4 (Winter 1979), pp. 91-101. 
trading nation and largest energy and commodity consumer, with the largest foreign exchange reserve, but also because it is a core country in the global financial system in terms of overseas investment, and in the global trading system - exporting mainly manufactured goods while importing raw materials. A developing nation notwithstanding, China has become a major creditor of the United States, financing American imports and spending. ${ }^{10}$ China's strong status as a vital part of the global capital "cartel" was firmly established when the International Monetary Fund (IMF) approved the Chinese Yuan's inclusion into the Special Drawing Rights (SDR) system, making the Chinese currency a major world currency. ${ }^{11}$

Moreover, the BRI, supported by Beijing-led financial institutions such as the Asian Infrastructure Investment Bank (AIIB) and the New Silk Road Foundation, seems to reflect Kautsky's ultra-imperialism theory by which Chinese capital and the capital from other core countries merge and intersect in order to jointly exploit the rest of the world in a form of amalgamated finance. As Lenin would have envisioned, the BRI facilitates China's emergence as a new center of capital, manufacturing and market sharing in the capitalist world system, which would inevitably intensify global competition and conflict with other core capitalist countries like the United States and India. As the fifth largest economy and third-largest by purchasing power parity (PPP), ${ }^{12}$ India has unarguably become a core capitalist country in terms of market size and overseas investment; it is also a major exporter of manufactured goods especially to the BCIM sub-region.

The dynamics of power politics have changed significantly as China joined in competition in the capitalist market. With China becoming the largest trading partner and investor of the Association of Southeast Asian Nations (ASEAN) Countries and most of the South Asian countries such as Bangladesh, Maldives, Pakistan and Sri Lanka, as well as the mushrooming

\footnotetext{
${ }^{10}$ Robert Longley, “How Much U.S. Debt Does China Really Own?” May 6, 2018, https://www.thoughtco.com/how-much-debt-does-china-own-3321769.

${ }^{11}$ Ibid, p. 21.

${ }^{12}$ IMF, IMF Annual Report 2017 (Washington, D.C.: IMF, 2017), https://www.imf.org/ external/pubs/ft/ar/2017/eng/pdfs/IMF-AR17-English.pdf.
} 
Chinese industrial parks in those countries, ${ }^{13}$ Washington feels increasingly threatened. The U.S. has thus adopted the "pivot-to-Asia" strategy under the Obama administration, followed by President Trump's "Indo-Pacific Strategy," to constrain and balance China's rapidly growing steps. As a potential strategic ally of the United States in balancing China, India perceives China's BRI as not only threatening its dominant role in the Indian Ocean region, but also becoming a big challenge to its export and resource mobilization in the world market. ${ }^{14}$ These concerns, combined with a natural sense of competition among powerful neighbors, constitute the ambivalence of India's strategic considerations about China.

With their shared goal to promote free market principles and democratic values, as well as their common interest in market sharing and resource security, India and the United States have been working toward a close partnership over the past decade, marked by President Obama's remarks during his visit to India in January 2015 and the framework agreement signed with Prime Minister Modi on expanding cooperation in the Indian and Pacific Oceans. ${ }^{15}$ Despite the ostensible negligence of the U.S. geo-strategic stance for the time being, the Trump administration put forward an "Indo-Pacific Strategy," by which the United States will coalesce with Japan, Australia and India as a quasi-alliance called "Quad" to deal with major security challenges, including a more "assertive" China. ${ }^{16}$

The ever closer Indo-U.S. strategic ties are critical to the participation of two small BCIM countries - Bangladesh and Myanmar - in the BCIM-EC and, more broadly, to their attitude towards China. Many foreign policy analysts in Bangladesh believe that the country was under heavy pressure from the United States and India with regard to its relationship

The U.S. and India have huge influence on the politics of Bangladesh and Myanmar.

${ }^{13}$ Ye Hailin, "The Strategic Landscape of South Asia and the Indian Ocean Region," in Wang Rong and Zhu Cuiping, eds., Annual Report on the Development of International Relations in the Indian Ocean Region (2014) (Berlin: Social Sciences Academic Press and Springer, 2015), p. 34.

${ }^{14}$ Zhu Cuiping, India's Ocean: Can China and India Coexist? (Singapore: Springer, 2018), p. 183.

${ }^{15}$ Annpurna Nautiyal, “US Security Strategy of Asian Rebalance: India's Role and Concerns," Strategic Analysis, Vol. 41, No. 1 (2017), pp. 14-33.

${ }^{16}$ The White House, National Security Strategy of the United States (Washington, D.C., 2017). 
with China. For example, due in large part to the fact that the Khaleda Zia government (2001-2006) engaged more in various aspects with China than the previous governments, the United States and India managed to make the Khaleda-led Bangladesh nationalist Party (BNP) expendable. ${ }^{17}$ As another example, the planned signing of an agreement between Bangladesh and China on building a deep-sea port at Sonadia Island of Cox's Bazar in Bangladesh with China's funding assistance has been shelved under India's diplomatic pressure on Bangladesh, even though the port is intended to be open to all countries in the BCIM sub-region. ${ }^{18}$ Similarly, since former U.S. Secretary of State Hillary Clinton's visit to Myanmar in late 2011 and the following visit by President Obama in November 2012, American influence over the country has been on the rise, contributing to the U.S. pivot to the Asia-Pacific. ${ }^{19}$ With the increasingly intense capitalist competition between China and the United States (and India, to lesser extent), it is difficult for the BCIM-EC to proceed as smoothly as previously expected.

\section{India's Security Dilemma}

The passive attitude of the Modi government toward building the BCIM-EC can be explained by the security dilemma theory, by which under anarchy "states assume the worst about each other's intentions" and hence tend to maximize their own security preparation as a defensive posture, which in turn triggers similar moves from potential rivals. ${ }^{20}$ The same logic applies to India and China. ${ }^{21}$ The relationship between India and China has been

${ }^{17}$ Anwara Begum, Sino-South Asian Relations: Missed Opportunities? (Dhaka: A. H. Development Publishing House, 2015), p. 360.

${ }^{18}$ Muinul Islam, “Regional Connectivity: Current Challenges for Bangladesh," Paper prepared for the regional seminar of the Bangladesh Economic Association held in Chittagong on March 19, 2016, p. 25, http://bea-bd.org/site/images/pdf/mui.pdf.

${ }^{19}$ Huang Chiung Chiu, "Balance of Relationship: The Essence of Myanmar's China Policy," Pacific Review, Vol. 28, No. 2 (2015), pp. 189-210.

${ }^{20}$ Kenneth N. Waltz, Theory of International Politics (New York: McGraw Hill, 1979).

${ }^{21}$ Florian P. Kühn, "Securing Uncertainty: Sub-state Security Dilemma and the Risk of Intervention," International Relations, Vol. 25, No. 3 (2011), pp. 363-380; and Sidra Tariq, "Sino-Indian Security Dilemma in the Indian Ocean: Revisiting the String of Pearls Strategy," Regional Studies, Vol. 34, No. 3 (Summer 2016), p. 4. 
marked by continuing strategic distrust, for there have been many unresolved issues since the 1950s, mainly including border disputes, the Tibet and Dalai Lama issues, the Pakistan factor, India's fear of China's "String of Pearls" strategy, and China's anxiety about potential encirclement by the United States through deepening strategic ties with India.

Raja Mohan, a leading analyst of India's foreign policy, lamented that India was on the verge of "losing" the Bay of Bengal to China. ${ }^{22}$ Indeed, India perceives its neighboring countries in South and Southeast Asia as a major part of its national security and its strategic sphere of influence; over the past decades, India has taken pains in different ways to shape South Asia, in particular the BCIM sub-region, to serve its political and economic interests. ${ }^{23}$ Under its "Look East"/"Act East" rubric, India has been promoting sub-regional cooperation through such connectivity initiatives as the "Bay of Bengal Initiative for Multi-Sectoral Technical and Economic Cooperation (BIMSTEC)," the "Trilateral Highway Project," and the Kaladan multi-modal project, in order to secure its position in the BCIM subregion. China's massive presence in the region, either through the BCIM-EC or by bilateral cooperation with regional countries, naturally sounds alarms for India.

A relatively new issue that is worth elaboration is China's "String of Pearls" strategy, a concept to describe China's growing bilateral trade, investment and developmentoriented infrastructure projects in India's neighborhood (Pakistan, Sri Lanka, Bangladesh and Myanmar), which are seen by many Indian scholars as a major threat to India's economic interests in the region. ${ }^{24}$ There is also widespread apprehension in India's military and security circles that these infrastructure projects may

${ }^{22}$ David Brewster, “Is India 'Losing' the Bay of Bengal?,” The Interpreter, March 19, 2014, https://www.lowyinstitute.org/the-interpreter/india-losing-bay-bengal.

${ }^{23}$ Christian Wagner, "The Role of India and China in South Asia," Strategic Analysis, Vol. 40, No. 4 (2016), p. 309.

${ }^{24}$ J. Jeganaathan, “OBOR and South Asia: Can India and China Cope with the Emerging 'New Normal' in the Region?," Fudan Journal of the Humanities and Social Sciences, Vol. 10, No. 2 (June 2017), pp. 161-178. 
be used for military purposes to expand China's presence in the Indian Ocean, ${ }^{25}$ despite Beijing's reiteration that its infrastructure and connectivity projects in the Indian Ocean region are mainly for commercial purposes and to ensure the security of sea lanes of communications, not for containing India. ${ }^{26}$ Besides considerations of major-power competition, India is concerned about the BCIM-EC because it might trigger mass movements of some ethnic groups in northeast India, where the BCIM-EC passes, for self-determination or even independence. ${ }^{27}$

\section{Ethnic Insurgency in Northeast India}

Even with the warming of India-China relations, ethnic insurgency in northeast India still pose security threats to the building of the BCIMEC. The $\mathrm{K} 2 \mathrm{~K}$ route of the Corridor will run through the Assam and Manipur provinces of India, both of which are subject to potential insurgency.

There are over thirty sub-tribes in Manipur province, where 90 percent of the landmass are hills and mountains. Due to a peculiar land regulation system under which the reserved hill tribes - mainly Nagas and Kukis are allowed to settle in the Imphal Valley, but no Hindu Meitei is allowed to buy land or settle in the hills, some Meiteis founded the United National Liberation Front (UNLF) in 1964, under the leadership of Samarendra Singh. The Meitei insurgency movements have spawned a plethora of armed forces from other ethnic groups - such as the National Socialist Council of Nagaland, the Kuki National Assembly (KNA), and the Kuki State Demand Committee (KSDC) - to protect their own aspirations. ${ }^{28}$ The KSDC even threatened to block entry of the BCIM Car Rally into

${ }^{25}$ Wagner, “The Role of India and China in South Asia," pp. 307-320.

${ }^{26}$ Richard W. Hu, “China's 'One Belt One Road' Strategy: Opportunity or Challenge for India?," China Report, Vol. 53, No. 2 (2017), pp. 107-124.

${ }^{27}$ Uberoi, “The BCIM Forum: Retrospect and Prospect," p. 17.

${ }^{28}$ Nameirakpam Bijen Meetei, "Emerging Trends in Ethnic Nationalism: Territoriality and Conflict in Manipur," History and Sociology of South Asia, Vol. 11, No. 1 (2017), pp. 55-67. 
"Kuki areas" of Manipur in 2013. ${ }^{29}$ As every group undertakes efforts to expand their respective ethnic boundaries by bringing in more communities into their fold, clashes within and among ethnic groups are not uncommon. Notably, a considerable proportion of attacks have been conducted around the capital of the province rather than in rural areas.

Assam is home to several ethnic communities demanding selfdetermination, sometimes upon the rally of such insurgent groups as the ULFA and the National Democratic Front of Bodoland (NDFB).$^{30}$ Both the NDFB and the ULFA confront the Indian army with guerrillas, but their operations also consist of bank robbery and assassination of government officials and political leaders. ${ }^{31}$ Besides, there are the United People's Democratic Solidarity (UPDS) calling for a separate territory for the Karbi tribe, the Hmar People's Convention-Democracy (HPC-D) demanding an independent Hmar state, as well as small armed groups such as Dima Halam Daogah (DHD) which occasionally engage in violent armed conflicts in the area; kidnapping for ransom, extortion, political abductions and killings, and violent enforcement of general strikes are some of the methods used by these militant groups. ${ }^{32}$

In general, ideology is not a primary force behind insurgency in northeast India, but most of the insurgent groups exist mainly to make money through extortion, kidnappings, tax collection from local people, demands for toll from development projects and attacks on communication links and energy infrastructure. Furthermore, northeast India is an important transit route for heroin trafficking from the neighboring "golden triangle" of Myanmar, Thailand and Laos to Europe, with local insurgent groups involved in this flourishing trade. Thus, the building of the BCIMEC will be risky through this region. Even when the Corridor is completed,

29 “KSDC Threatens to Block BCIM Car Rally in Manipur's Kuki Areas," Times of India, February 13, 2013, https://timesofindia.indiatimes.com/city/guwahati/KSDC-threatens-toblock-BCIM-car-rally-in-Manipurs-Kuki-areas/articleshow/18635655.cms.

${ }^{30}$ Lawrence E. Cline, “The Insurgency Environment in Northeast India," Small Wars and Insurgencies, Vol. 17, No. 2 (June 2006), pp. 126-147; and Kunal Mukherjee, "The Conflict in the Indian Northeast," Defence Studies, Vol. 14, No. 2 (2014), pp. 111-133.

${ }^{31}$ Cline, “The Insurgency Environment in Northeast India," p. 115.

32 Åshild Kolås, "Framing the Tribal: Ethnic Violence in Northeast India," Asian Ethnicity, Vol. 18, No. 1 (2017), pp. 22-37. 
transportation of personnel and goods may still face constant security threats from local insurgency.

\section{Ethnic insurgency} in northeast India and Myanmar pose serious security challenges to the BCIM-EC.

\section{Ethnic Insurgency in Myanmar}

In Myanmar, the BCIM-EC will run through the Shan, Chin and Rakhine states, which are also under constant ethnic insurgency rooted in the ethnic division during the colonial period. ${ }^{33}$ The Shan state has been plagued by armed conflicts as insurgent groups like the Shan State Army (SSA) and the Restoration Council of Shan State (RCSS) continue fighting for self-determination; the Chin state, located to the eastern border of northeast India and southeastern border of Bangladesh, is often raged by guerrilla warfare conducted by the Chin National Front (CNF), the Chin National Army (CNA), the Naga National Council (NNC), and other smaller militant groups; ${ }^{34}$ and the Rakhine state, formerly the Arakan state, has witnessed independent movement and guerrilla attacks led by the Arakan Liberation Party and later on the Arakan Army, which is allied with the Kachin Independence Organization (KIO) and Myanmar National Democratic Alliance Army (MNDAA).

Many of those insurgent groups are actively involved in small arms and drug business. For decades, hostility and clashes among competing insurgent groups have contributed to the proliferation of illegal arms in Myanmar, which has become a transit route of small arms to other countries, especially to northeast India. ${ }^{35}$ In addition, these insurgent groups collect taxes from local people and exact toll from development projects in regions under their influence. Therefore, the prevailing insurgency in

${ }^{33}$ Anshuman Behera, "Insurgency, Drugs and Small Arms in Myanmar," Strategic Analysis, Vol. 41, No. 1 (2017), pp. 34 -48. See also Ashley South and Christopher M. Joll, "From Rebels to Rulers: The Challenges of Transition for Non-state Armed Groups in Mindanao and Myanmar," Critical Asian Studies, Vol. 48, No. 2 (2016), pp. 168-192.

${ }^{34}$ Ibid.

${ }^{35}$ Behera, “Insurgency, Drugs and Small Arms in Myanmar," p. 44. 
the Shan, Chin and Rakhine states of Myanmar may also present lasting security challenges to the building of the BCIM-EC.

\section{The Rohingya Issue Between Bangladesh and Myanmar}

Rohingyas have lived in Myanmar for centuries and they are the descendants of Muslim Arabs, Moors, Persians, Turks, Mughals and Bengalis. ${ }^{36}$ They have their own language, culture, and heritage in the Arakan state which had been an independent kingdom for 2,000 years before becoming part of Myanmar in 1785. After Burmese King Radaw Yaya invaded Arakan in 1784, majority Burman Buddhists persecuted the Rohingyas. Some scholars estimate that about 35,000 Rohingyas fled to Chittagong of Bangladesh then. ${ }^{37}$ That is the root cause of the Rohingya Issue.

In 1977, the military government of Myanmar registered all citizens prior to the national census, but excluded Rohingyas from this census. ${ }^{38}$ Rohingya has also been excluded from the 135 ethnic groups recognized by the Myanmar government, thus leading to enduring torture, rape, killings and social trauma in the Rohingya community. For instance, a militant action ordered by General Ne Win's government in February 1978 claimed the lives of nearly 10,000 Rohingyas and drove over 200,000 Rohingya refugees across the border of Bangladesh. ${ }^{39}$ As the Bangladesh government continues protesting the repressive measures of the Myanmar government toward ethnic and religious minorities, the political relationship between them has been under immense tension.

${ }^{36}$ Nehginpao Kipgen, “Conflict in Rakhine State in Myanmar: Rohingya Muslims' Conundrum," Journal of Muslim Minority Affairs, Vol. 33, No. 2 (2013), pp. 298-310.

${ }^{37}$ F. Alam, "Rohingya Refugee in Bangladesh: Humanitarian Assistance, Internal Disturbances and the Role of External Factors," in N. Uddin ed., To Host or To Hurt: CounterNarratives on Rohingya Issue Bangladesh (Dhaka: ICDR, 2012), pp. 142-152.

${ }^{38} \mathrm{Akm}$ Ahsan Ullah, "Rohingya Refugees to Bangladesh: Historical Exclusions and Contemporary Marginalization," Journal of Immigrant \& Refugee Studies, Vol. 9, No. 2 (2011), pp. 139-161.

${ }^{39}$ Syeda Naushin Parnini, "The Crisis of the Rohingya as a Muslim Minority in Myanmar and Bilateral Relations with Bangladesh," Journal of Muslim Minority Affairs, Vol. 33, No. 2 (2013), pp. 281-297; and Kipgen, "Conflict in Rakhine State in Myanmar." 
Bangladesh experienced another round of inflow of Rohingyas through its land and sea borders in 2012 when more than 120,000 Rohingyas fled to Cox's Bazar of Bangladesh during a riot between the majority Buddhist community and the Muslim Rohingya in western Rakhine. ${ }^{40}$ After Rohingyas began organizing themselves and formed the Arakan Rohingya Salvation Army (ARSA) in 2013, the Myanmar government launched more operations against Rohingyas, resulting in nearly 10,000 dead and more than 600,000 taking shelter in Bangladesh. ${ }^{41}$

The Rohingya issue hinders Myanmar-

Bangladesh

cooperation on the BCIM-EC.

The Rohingya crisis in the Rakhine state of Myanmar undermines the relations between Bangladesh and Myanmar and destabilizes the situation on the borders of the two countries, as many jobless Rohingyas are involved in various criminal activities like murder, smuggling, prostitution, drug dealing, and proliferation of small arms in the border areas of Bangladesh. ${ }^{42}$ Thus, the Rohingya crisis has not only given rise to enduring insecurity in the Rakhine state and the Bay of Bengal region, but also hindered cooperation between Myanmar and Bangladesh in building the BCIM-EC.

\section{Experts' Perception of the Major Challenges to the BCIM-EC}

Given the multiple security challenges to the BCIM-EC, a key-informant interview was conducted in early 2018 to find out the severity of different challenges. A total of 30 informants (15 each from China and Bangladesh) including experts, scholars, and practitioners in related fields were asked to give their thoughts on the major security challenges to the BCIM-EC. Here, "geopolitical challenges" include the potential U.S.-India ties for containing China and India's non-cooperation stance, while "diplomatic pressure" refers to India's and the United States' diplomatic pressure on Bangladesh and Myanmar in cooperation with China; "ethnic

\footnotetext{
${ }^{40}$ Parnini, "The Crisis of the Rohingya as a Muslim Minority in Myanmar," p. 295.

${ }^{41}$ Mahfuz Anam, “Rohingyas Crisis: A Concern for the Region," Daily Star, October 9, 2017. ${ }^{42}$ Alam, "Rohingya Refugee in Bangladesh," p. 145.
} 
Table 1. Experts' Perceptions of Major Security Challenges to the BCIM-EC.

\begin{tabular}{lrcccc}
\hline & \multicolumn{5}{c}{ Percentage } \\
\cline { 2 - 6 } Factor & Other & Disagree & Strongly Disagree & Agree & Strongly Agree \\
\hline Geopolitical Challenges & 6.7 & 13.3 & & 53.3 & 26.7 \\
Diplomatic Pressure & 10.0 & 23.3 & 3.3 & 43.3 & 20.0 \\
Ethnic Insurgency & 6.7 & 26.7 & & 43.3 & 23.3 \\
Rohingya Issue & 3.3 & 33.3 & 46.7 & 16.7 \\
\hline
\end{tabular}

Source: Compiled by the authors.

insurgency" mainly refers to the insurgency in northeast India and Myanmar; and the "Rohingya issue" refers to the political and security tensions between Bangladesh and Myanmar over the latter's policy toward Rohingyas. All the questions on the challenges are open-ended for additional comments from the informants. The results of the survey are presented in Table 1.

As shown in the table, a total of 80 percent of informants agree or strongly agree that "geopolitical challenges" are a major challenge to the building of the BCIM-EC, followed by 67 percent on "ethnic insurgency," 64 percent on the "Rohingya issue," and 63 percent on "diplomatic pressure." Their answer to additional questions indicates that most of the informants view India's non-cooperation stance as the biggest challenge, while other security challenges, however serious they are, cannot affect the construction of the BCIM-EC fundamentally.

Apart from the statistical data, several Bangladeshi informants maintain that a participating member will only devote to the building of the Corridor when it feels it has much to gain from the project. Considering that India has refrained from joining in the project while developing its own eastward connectivity programs instead, it is of great necessity to give India more incentives to step up its efforts. For now, it seems feasible to

Most experts see strategic distrust between India and China as the biggest challenge to the BCIM-EC. build the Corridor along two routes - from Southwest China to Myanmar, and from Mandalay of Myanmar to Chittagong of Bangladesh — as a good model for further extension of the Corridor. 


\section{How to Tackle the Challenges?}

Given that India's passive stance and the influence of Indo-U.S. ties on Bangladesh and Myanmar are two major challenges to building the BCIM-EC, substantial efforts should be taken to enhance India's interest while minimizing the negative effect of the U.S. influence in the region. Undoubtedly, there is an enduring "trust deficit" or "strategic distrust" in the India-China relationship. In this context, incremental improvement of the bilateral relationship and growing Chinese engagement with Bangladesh and Myanmar are necessary steps in building trust and enhancing cooperation among the three parties.

Some Russian geo-strategic theorists argue that the USSR lost the Cold War mainly due to its failure to construct a solid strategic alliance with "Rimland" countries in Central Europe, Middle East, South Asia and East Asia; instead of making enemies with China, the USSR should have adopted a more humble and accommodating attitude toward a unified and rising China. ${ }^{43}$ Although times has changed and China has had no intention to foster a self-centered alliance against the United States or any other competing power, it should consolidate its neighboring relations to maintain a peaceful and cooperative environment for its peaceful development. Indeed, China has already adopted a friendly approach to neighborhood diplomacy since 2013 that is intended to strengthen its relations with neighboring regions, in particular South and Southeast Asia. ${ }^{44}$

Since India is a major developing country and emerging power in China's southern neighborhood, China should better manage its relations with India so as to facilitate its peaceful rise in global economic and political arenas. And the key to reduce distrust and strengthen mutual ties between them is to enhance people-to-people exchange and cooperation in various fields on bilateral, regional and global platforms, based on a sober understanding of each other's strategic intention as well as the potential benefits

\footnotetext{
${ }^{43}$ See, for example, Ingram Alan, "Alexander Dugin: Geopolitics and Neo-fascism in Post-Soviet Russia," Political Geography, Vol. 20, No. 8 (2001), pp. 1029-1051; and Patrick Sullivan, Geopolitics (London: Croom Helm, 2010), p. 31.

${ }^{44}$ Antonina Habova, "Silk Road Economic Belt: China's Marshall Plan, Pivot to Eurasia or China's Way of Foreign Policy," KSI Transactions on KNOWLEDGE SOCIETY, Vol. 8, No. 1 (March 2015), pp. 64-70.
} 
and opportunities for cooperation. ${ }^{45}$ If China and India start working on a joint project - however small it is - on the BCIM-EC, it will greatly boost the confidence of all participating countries and further deepen the mutual understanding and trust between the two great Asian powers.

Given India's non-cooperation stance for the time being, China should consider an alternative option that was originally proposed by Bangladesh: connecting its Kunming city with Chittagong of Bangladesh and Yangon of Myanmar by both road and rail, and then extending to Thailand, Malaysia and Singapore, as the spine of the Trans-Asian road network. ${ }^{46}$ Such a grand plan is already underway on the ASEAN side, such as the ongoing Jakarta-Bandung high-speed rail project and the Pan-Asian railway network including the China-Laos and China-Thailand railways, among other routes.

Nevertheless, it takes two to tango. The building of the BCIM-EC has made little progress since Narendra Modi became Indian Prime Minister in May 2014. Worried about China's growing influence in the Bay of Bengal region and northeast India, the Modi government has been very cautious about the potential impact of the BCIM-EC. ${ }^{47}$ However, New

Engaging closely in the BCIM-EC is in the best interest of India. Delhi needs to face the reality that, with its rising power, China is bound to exert more influence in the regions that used to be considered as India's "sphere of influence"; India's best option is not to resist such influence by keeping those regions in slow developing motion like before, but to engage actively in the joint development project and tap into the opportunities brought by the project to manifest its regional leadership and contribution.

Considering its historical, political and cultural ties with Southeast Asia and other South Asian countries, India can better secure its economic

${ }^{45} \mathrm{Zhu}$, India's Ocean: Can China and India Coexist?, p. 188.

${ }^{46}$ Mohd Aminul Karim and Faria Islam, "Bangladesh-China-India-Myanmar (BCIM) Economic Corridor: Challenges and Prospects," Korean Journal of Defense Analysis, Vol. 30, No. 2 (June 2018), pp. 283-302.

${ }^{47} \mathrm{Hu}$, “China's 'One Belt One Road' Strategy: Opportunity or Challenge for India?,” pp. 107-124. 
interests and geo-strategic position in the region by expanding its overland access through the BCIM-EC. With a number of infrastructure projects linking various sub-regions in Asia, India will not only benefit from the vast job and business opportunities along the Corridor, but also from deeper economic integration with other parts of the world, especially China, which, in turn, contributes to confidence building between them.

In order to ensure security along the Corridor, a joint BCIM security mechanism should be established to address various security challenges, such as local insurgency, trans-border crime, natural disaster and transportation accidents. That would require timely information sharing and cooperation among the security agencies of the four BCIM countries. In the short term, they can form special security teams for ad hoc security operations. ${ }^{48}$ In the longer run, a permanent security force joined by respective governments should be set up to address various security issues under a comprehensive framework agreed upon by the four countries. Besides, Myanmar and Bangladesh should make more effort - with the support of India, China and the United Nations - to tackle the Rohingya issue, the key of which is that the Rohingya people are settled down with full citizenship. Ultimately, success of the BCIM-EC depends on how China and India, as two major powers of the region, will enhance their mutual strategic trust and cooperation, so as to present stronger leadership in regional integration and development.

${ }^{48}$ Roshan Iyer, “BCIM Economic Corridor: Facilitating Sub-Regional Development," Special Report 187, Institute of Peace and Conflict Studies, May 2017, http://www.ipcs.org/ issuebriefs/issuebriefpdf/IPCS_Special_Report187BCIM_EconomicCorridor_RIyer_May2017. PDF. 